JURNAL AL BAYAN: JURNAL JURUSAN PENDIDIKAN BAHASA ARAB

p-ISSN 2086-9282 | e-ISSN 2549-1229

\title{
Technique and Quality Translation of Idhafi in The Matan Hadits of Arba'in al-Nawawi
}

\author{
Muhammad Irfan Faturrahman ${ }^{1}$, Yoyo $^{2 *}$, Abdul Razif Zaini ${ }^{3}$ \\ ${ }^{1}$ Arabic Language and Literature Study Program Universitas Ahmad Dahlan Yogyakarta, Indonesia \\ ${ }^{2}$ Arabic Language and Literature Study Program Universitas Ahmad Dahlan Yogyakarta, Indonesia \\ ${ }^{3}$ Arabic Language and Linguistics Study Program Islamic International University College Selangor, \\ Malaysia
}

Article History:

Received : February 8, 2020

Revised : March 20, 2020

Accepted : April 30, 2020

Published : December 01, 2020

Keywords:

Hadits of Arba'in; Molina Albir;

Quality; Translation

*Correspondence Address: yoyo@bsa.uad.ac.id

\begin{abstract}
The accuracy of translation from the source language (SL) to the targeted language (TL) is not easy work. The translator should act as the connector between the writer of the work and the reader of the translation. The paper tries to analyses the translation of Arbai'n An-Nawawi by using the techniques offered by Molina Albir. This is a qualitative study that focuses on how the translator translated the Idhofi case in the Matan of Araba'in as the material object of this paper. Besides, the authors distributed questionnaires to assess the quality of the translation. The paper found that the translator uses 11 techniques that consist of 64 data of literal, 25 data of amplification, 21 data of borrowing, 12 data adaptation techniques, 6 data of compensation, 2 data of discursive creation, 2 data of reduction, 1 data of generalization, 1 data of modulation, and 1 data of transposition technique. Meanwhile, from the quality of the translation, it can be concluded that the compensation technique is much more acceptable, with $81 \%$ very accurate, $73 \%$ acceptable, and $77 \%$ rated high legibility. It is because the method helps the reader to understand the meaning, message, and goals to be conveyed.
\end{abstract}

\section{Introduction}

The purpose of the translation activities is to understand the thoughts, ideas, culture, and knowledge of other nations who have different styles ${ }^{1}$. Translation activities can be divided into two types, namely oral translation or what is often referred to as fauriyah translation and written translation. ${ }^{2}$ Meanwhile, translation studies divided into two types, namely descriptive translation studies, and translation theory studies ${ }^{3}$. In the

1 Akmaliyah, "Model Dan Teknik Penerjemahan Kalimat Bahasa Arab Ke Dalam Bahasa Indonesia," Al-Tsaqafa: Jurnal Ilmiah Peradaban Islam, 13 (01) (2016): 125-34.

2 Peeter Torop, “Translation as Translating as Culture," Sign Systems Studies, 30, no. 2 (2002): 593605.

3 Mangatur Nababan, “Aspek Genetik, Objektif, Dan Afektif Dalam Penelitian Penerjemahan," Linguistika: Buletin Ilmiah Program Magister Linguistik Universitas Udayana, 14 (2007): 15-23 
field of descriptive translation studies, it has two objects, namely the work of translation and the process of translation ${ }^{4}$.

Translation activities certainly require translation techniques or styles ${ }^{5}$. Translation techniques are procedures or procedures for analyzing ${ }^{6}$ and classifying translation equivalents from source languages to target languages and can be used in a variety of lingual units ${ }^{7}$. In translation activities, the use of techniques used by translators is not an important thing ${ }^{8}$. The most important thing for a translator is the technique chosen can fulfill the purpose of the translation'. Among the objectives of the translation $^{10}$, activity as a communication tool that connects the writer in the source language with the reader in the target language, and the translator as the mediator or the liaison of both ${ }^{11}$. The correct use of translation techniques from the source language (SL) to the target language (TL) dramatically influences the quality of the translation, ${ }^{12}$ and this can be proven by the reader's understanding of the message, intent, or taste conveyed by the author in the source language.

This study aims to classify the theory of translation used by translators and assess the quality of reading in the translation of noun phrases in the An-Nawawi Arbain Hadith. Translation of the Hadith is a vital ${ }^{13}$ thing to do in Indonesia because it is a country with a majority Muslim population, so they should understand the teachings of their religion through the al-Qur'an and al-Hadith. In understanding these two main sources of Islam, Indonesian and non-Arabic speaker in general often experience

\footnotetext{
4 Mangatur Nababan, "Kecenderungan Baru Dalam Penerjemahan,” Englonesian: Jurnal Ilmiah Linguistik dan Sastra, 2, no. 1 (Mei 2006): 68-73.

5 Ángeles Carreres, and María Noriega-Sánchez., "Translation in Language Teaching: Insights from Professional Translator Training," The Language Learning Journal, 39, no. 3 (2011): 281-97.

6 Harald Martin Olk, "Cultural References in Translation: A Framework for Quantitative Translation Analysis,” Perspectives, 21, no. 3 (2013): 344-57.

${ }^{7}$ Lucía Molina and Amparo Hurtado Albir, "Translation Techniques Revisited: A Dynamic and Functionalist Approach," Les Presses de l'Université de Montréal, Journal des traducteurs, 47, no. 4 (2002): 498-512, id.erudit.org/iderudit/008033ar https://doi.org/10.7202/008033ar.

8 Monireh Akbari, "Strategies for Translating Idioms," Journal of Academic and Applied Studies (Special Issue on Applied Linguistics), 3, no. 8 (2013): 32-14.

${ }^{9}$ Daniel Gouadec, Translation as a Profession, vol. 73 (Amsterdam: John Benjamins Publishing, 2007): 106.

${ }^{10}$ Iryna Karpivna Kobiakova and Svitlana Oleksiivna Shvachko, 'Teaching Translation: Objectives and Methods', Advanced Education, 2016, 9-13.

${ }^{11}$ Mangatur Nababan, 'Kecenderungan Baru Dalam Penerjemahan', Englonesian: Jurnal Ilmiah Linguistik Dan Sastra, 2.1 (2006), 68-73 (p. 70).

${ }^{12}$ Esposito and Noreen, 'From Meaning to Meaning: The Influence of Translation Techniques on Non- $\quad$ English Focus Group Research’, Qualitative Health Research, 11.4 (2001), 568-79.

${ }^{13}$ Latifah Abdul Majid, and Nurullah Kurt., "Bahr Al-Madhi: Significant Hadith Text Sciences for Malay Muslims as a Tool for Political Teaching during Twentieh Century," Mediterranean Journal of Social Sciences, 5, no. 20 (2014): 2249.

209 | Jurnal Al Bayan: Jurnal Jurusan Pendidikan Bahasa Arab, 12 (2): 208-224 (2020)
} 
difficulties due to the lack of mastery of Arabic. ${ }^{14}$ It is because of the Arabic as a Semitic family which has complex scripts. ${ }^{15}$

A translation study is an exciting field of study. It is because, in translating a text, a translator is not only required to master the source language and target language, but the translator is also necessary to understand the social and cultural conditions in the source language and target language. ${ }^{16}$ Arabic, as the SL, has its complexity, such as its grammatical structure. ${ }^{17}$ Besides, the Arabic used in religious text is formal Arabic or Fushā in where this language regarded by the Muslims as sacred language. ${ }^{18}$

Previous studies in the area of Arabic translation in the Indonesian context are as follows. First, research conducted by Anindia Ayu Rahmawati et al.; in Kajian Teknik Penerjemahan Dan Kualitas Terjemahan Ungkapan Yang Mengandung Seksisme Dalam Novel The Mistress's Revenge Dan Novel The $19^{\text {th }}$ Wife. This study focused on the technique and quality translation of sexism within the novel. ${ }^{19}$ Second, a paper titleled Gaya Bahasa, Teknik Penerjemahan, Dan Kualitas Terjemahan Dalam Dongeng Disney Dwibahasa Berjudul Cinderella: My Bedtime Story Dan Tinkerbell And The Great Fairy Rescue. The results of the study indicate that based on the type of lexis, noun group structure, and clause structure, the first fairy tale is in the continuum of the language style tends to be oral, and the second fairy tale is in the continuum of the written, oral form. Some of the translation techniques used in both stories include standard equivalence

14 Arif Mohammed Mufleh Alsrhid, 'Difficulties Face by Foreign Students in Learning Arabic Language Programs for Non-Native Speakers (Evaluation Study)', Learning, 4.2 (2013), 160-70; Wahyudi Buska, Yogia Prihartini, and Nur Hasnah, 'Analysis of Students' Arabic Proficiency for Vocabulary Mastery in State Islamic Junior High School in Muaro Jambi', INNOVATIO: Journal for Religious Innovation Studies, 18.1 (2018), 51-62 <https://doi.org/https://doi.org/10.30631/innovatio.v18i1.40>.

${ }^{15}$ John Huehnergard, 'Arabic in Its Semitic Context', in Arabic in Context (Leiden: Brill, 2017), 3 34 <https://doi.org/https://doi.org/10.1163/9789004343047_002>; Bernard Lewis, Semites and AntiSemites: An Inquiry into Conflict and Prejudice (New York and London: WW Norton \& Company, 1999), 42; Clive Holes, Modern Arabic: Structures, Functions, and Varieties (Washington: Georgetown University Press, 2004), 1-5.

16 Albrecht Neubert, 'Competence in Language, in Languages, and in Translation', Benjamins Translation Library, 38 (2000), 3-18 <https://doi.org/https://doi.org/10.1075/btl.38.03neu>.

${ }^{17}$ Yoyo Yoyo and Abdul Mukhlis, 'Historiography of the Arabic Grammar in Europe: The Legacy of Wright's Arabic Grammar', in First International Conference on Progressive Civil Society (ICONPROCS 2019,(Atlantis Press, 2019), 212-15, <https://doi.org/https://doi.org/10.2991/iconprocs19.2019.45>.

${ }^{18}$ Yoyo Yoyo and others, 'High Variety Vs Low Variety Culture in the Arabic Language: The Tensions between Fushā and 'Âmiyya in the Contemporary Arab World', Arabi: Journal of Arabic Studies, 5.1 (2020), 25-32<https://doi.org/http://dx.doi.org/10.24865/ajas.v5i1.195>.

${ }^{19}$ Anindia Ayu Rahmawati, Nababan Nababan, and Riyadi Santosa, 'Kajian Teknik Penerjemahan Dan Kualitas Terjemahan Ungkapan Yang Mengandung Seksisme Dalam Novel The Mistress's Revenge Dan Novel The 19th Wife', Prasasti: Journal of Linguistics, 1.2 (2016), 249-70, <https://doi.org/https://doi.org/10.20961/prasasti.v1i2.1032>. 
techniques, variations, amplification, reduction, transposition, modulation, and linguistic compression. The use of these techniques can maintain a fairytale language style and produce an accurate and legible translation, although the level of acceptance is lacking. ${ }^{20}$

Third, a journal titled Kajian Terjemahan Metafora yang Menunjukkan Sikap dalam Buku Motivasi The Secret. Results of the analysis showed: (1) There are 15 kinds of translation techniques of total 292 data found in the translation of metaphor that shows the attitude in the book The Secret; (2) an evaluation of the quality of translations shows high-quality results; (3) The application of these techniques provide the translation impact of young quite positive about the quality of translation; (4) the use of translation technology produces high its quality of translation as to accommodate differences in the rules of language and culture as well as divert shape, sort of meaning, and attitude. ${ }^{21}$ Fourth, a journal titled Strategi dan Teknik Terjemahan Novel Arab dalam Kalangan Pelajar Universiti. The findings show that the overall use of translation learning strategies among university students was at a moderate level. The study also shows that there were two categories of translation learning strategies used at a moderate level, which were translation writing strategies and mixed translation strategies. ${ }^{22}$

The fifth, a paper titled Analisis Terjemahan Gaya Bahasa Repetisi Dalam Novel A Thousand Splendid Suns, Teknik Dan Kualitasnya (Kajian Penerjemahan Dengan Pendekatan Stilistika). This study concludes that the implementation of 10 translation techniques had a positive impact on the accuracy and acceptability of its translation. ${ }^{23}$ The difference between the research conducted by the researcher and the literature review above lies in the formal object and the material object. The formal object of this paper is idhafi phrase, while the material is Arba'in An-Nawawi.

${ }^{20}$ Yogi Rohana, Riyadi Santosa, and Djatmika Djatmika, 'Gaya Bahasa, Teknik Penerjemahan, Dan Kualitas Terjemahan Dalam Dongeng Disney Dwibahasa Berjudul Cinderella: My Bedtime Story Dan Tinkerbell And The Great Fairy Rescue.', PRASASTI: Journal of Linguistics, 2.1, 150-66, <https://doi.org/https://doi.org/10.20961/prasasti.v2i1.1736>.

21 Retno Hendrastuti, 'Kajian Terjemahan Metafora Yang Menunjukkan Sikap Dalam Buku Motivasi The Secret', TransLing, 1.1 (2013), 21-35.

22 Harun Baharudin, 'Strategi Dan Teknik Terjemahan Novel Arab Dalam Kalangan Pelajar Universiti (Arabic Novel Translation Strategies and Techniques Used among University Students)', GEMA Online ${ }^{\circledR}$ Journal of Language Studies, $17.4 \quad$ (2017), 225-43, <https://doi.org/http://dx.doi.org/10.17576/gema 2017-1704-15>.

23 Anshoffy Murtafi, Nababan Nababan, and Djatmika Djatmika, 'Analisis Terjemahan Gaya Bahasa Repetisi Dalam Novel a Thousand Splendid Suns, Teknik Dan Kualitasnya (Kajian Penerjemahan Dengan Pendekatan Stilistika)', PRASASTI: Journal of Linguistics, 2.1 (2017), 1-20, <https://doi.org/https://doi.org/10.20961/prasasti.v2i1.1664>. 


\section{Method}

This research was conducted on the translation of Arba'in An-Nawawi Hadith. To bridge this research, the methodological foundation that researchers use is a qualitative method. The qualitative method is a research method which is based on the philosophy of postpositivism $^{24}$, which is used to examine the condition of natural objects, producing descriptive data in the form of written or oral words where the researcher as the core means. Data collection techniques are carried out by triangulation (combined), data analysis used is inductive/qualitative, and the results of qualitative research are more inclined to meaning than generalization. In this study, researchers used a qualitative method with a descriptive approach. Data collection is done by collecting data related to the problem under study. The reason for the researchers to use descriptive qualitative methods is to find out the extent of the use of Molina and Albir translation techniques and its influence on the quality of the translation of the Arba'in An-Nawawi Hadith phrase.

In this paper, the data obtained are intrinsically descriptive, which means that the information that has been taken is limited to the material or data that is used as the object of research. Next, the authors analyzed the use of translation techniques and tested the quality of the translation of the target language by distributing questionnaires to several respondents. The criteria for respondents in this study are 1) students of Arabic Language and Literature of Ahmad Dahlan University in the $5^{\text {th }}$ semester, 2) they never took the theory of translation courses, 3) they master the target language (Indonesian).

\section{Result and Discussion}

\section{Translation Techniques in The Arba'in An-Nawawi}

In this study, the researchers focused on the translation of the idhafi phrase in the Hadith Arba'in An-Nawawi. In this book, researchers find 139 idhafi phrases that are translated using 11 translation techniques. However, in this article, researchers will discuss the five most commonly used translation techniques. The decision to choose these five techniques is based on its frequent use in the translation. These five techniques are literal translation, amplification, borrowing, adaptation, and compensation.

a) Literal Translation

${ }^{24}$ Isabella Mayer, "Qualitative Research with a Focus on Qualitative Data Analysis," International Journal of Sales, Retailing \& Marketing, 4, no. 9 (2015): 53-67. 
A literal translation is a translation technique used by translators by translating the phrase word for word. In the Hadith Arba'in An-Nawawi, there are 64 idhafi phrases are translated using a literal translation, but in this study, one sample will be taken randomly by the researcher. The example is the phrase as follow إنَّ مِمَّما أَدْرَكَ الَنَّاسُ مِنْ Sesungguhnya di antara perkataan kenabian terdahulu yang diketahui manusia ialah." In this phrase, there is the idhafi phrase which is translated using literal translation techniques, namely, "كلام التبوة". The word كلام in the dictionary ${ }^{25}$ has the meaning as "perkataan or percakapan." Whereas the word التبوة in the dictionary ${ }^{26}$ has the meaning "hal jadi nabi". Therefore the phrase of idhafi كلام النبوة is correctly translated using literal translation techniques because it makes it easy for readers to understand.

b) Amplification

Amplification is a translation technique that explicitly or paraphrases implicit information in the source language. In the Hadith Arba'in An-Nawawi, there are 25 idhafi phrases which are translated using amplification, but in this study, one sample will be

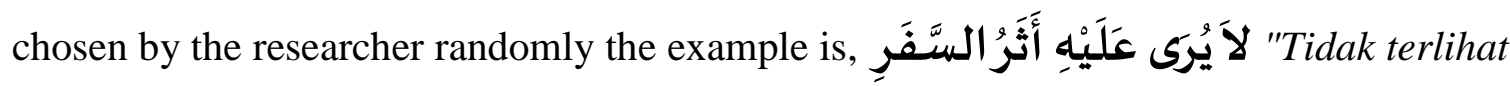
padanya bekas perjalanan jauh." In this phrase, there is the idhafi phrase which is

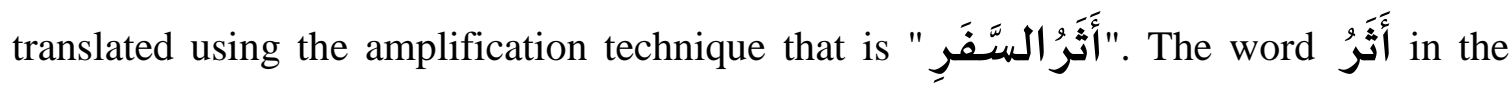
dictionary ${ }^{27}$ has the meaning "hadits or bekas", Whereas the word السنَّفَرِ in the dictionary ${ }^{28}$ has the meaning "perjalanan". However, in the case of this translation, the translator adds information with the words "jauh". The purpose of the technique is that

${ }^{25}$ Ahmad Warson Munawwir, Kamus Al-Munawwir Arab-Indonesia (Surabaya: Pustaka Progressif, 1997): 1227

${ }^{26}$ Al-Munawwir, 1382..

${ }^{27}$ Al-Munawwir, 7.

${ }^{28}$ Al-Munawwir, 636.. 
the translator can convey the message accurately. So that the translation of the idhafi phrase of أثر السفر becomes "bekas perjalanan jauh".

c) Borrowing

Borrowing is a translation technique used by translators by borrowing words or phrases from the source language. In the Hadith Arba'in An-Nawawi, 21 idhafi phrases are translated using the borrowing technique, but in this study, one sample will be taken that is chosen by the researcher randomly. The example is, وَمَا اجْتَمَعَ قَوْمَ فِ بَيْتِ مِنْ Tidaklah suatu kaum berkumpul di salah satu rumah Allah (masjid) untuk membaca kitabullah dan mempelajarinya diantara mereka." In this data, there is an idhafi phrase which is translated using the borrowing technique namely, كتاب الله. The word كتاب in the dictionary ${ }^{29}$ has the meaning "kitab, surat, buku, perlu, and hukum", Whereas the word الله it is lafdzun jalalah which is still interpreted as lafadz Allah.

In the translation of the idhafi phrase كتاب الله, the translator uses the borrowing translation technique to translate this phrase. The translator translates the word كتاب in the source language to the target language with the word kitabu, and translates lafadz الله with the phrase "Allah" so that it becomes "Kitabullah."

d) Adaptation

Adaptation is a translation technique used translators by replacing the cultural elements of the source language with decorative items that have the same characteristics in the target language, and those cultural elements are familiar to the target reader. In the Hadith Arba'in An-Nawawi, 12 idhafi phrases are translated using adaptation, but in this study, one sample will be chosen by the researcher randomly the example is, وَأْغَثْم مَا

"Sedangkan dosa itu adalah sesuatu yang mengganjal di hatimu."In this 
data, there is the phrase idhafi which is translated using adaptation techniques, نفسك.

The word نفس in the dictionary ${ }^{30}$ has the meaning "roh, nyawa, tubuh diri seseorang, darah, niat, orang, kehendak". Whereas (\$) is a pronoun (dhomir), which means "kamu". In the case of the translation of the phrase idhafi (نفسك), the translator replaces the source language culture element (SL) with the target language culture element (TL). This is because in the source language (SL), something that blocks the feeling is in the heart. Translation using adaptation techniques is also intended so that readers in the target language can understand the message conveyed in the text.

e) Compensation

Compensation is a translation technique used by translators by introducing information elements or stylistic influences of the source language text elsewhere in the target language text. In the Hadith Arba'in An-Nawawi, six idhafi phrases are translated using compensation techniques, but in this study, one sample will be taken by the researcher the example is, الْبِرَحسُنْنُ الْخُلْقِ "Kabajikan itu adalah akhlak yang baik." In this data, there is the phrase idhafi which is translated using compensation techniques, in the dictionary ${ }^{31}$ has the meaning "kebagusan and kebaikan." Whereas the word الخلقin the dictionary ${ }^{32}$ has the meaning "akhlak and perangai".

In the translation of the phrase idhafi حسسن الخلق, the translator uses compensation translation techniques. The translator indicates this by adding the conjunction "yang." The translator introduces the stylistic influence of the source language text in the target language text.

\section{Analysis of Translation Quality in the Arba'in An-Nawawi}

\footnotetext{
${ }^{29}$ Al-Munawwir, 1187.

${ }^{30}$ Al-Munawwir, 1446.

${ }^{31}$ Al-Munawwir, 265.

${ }^{32}$ Al-Munawwir, 364.
} 
In this section, an assessment of the quality of translations will be examined in terms of accuracy, acceptability, and transparency. As for the evaluation on the discussion of the quality of this translator using questionnaires distributed to respondents from Arabic Language and Literature students with the criteria, 1) Ahmad Dahlan University Arabic Language and Literature students in semester 5, 2) Have taken courses in translation theory, 3) Mastering the target language (Indonesian). Researchers managed to collect 47 respondents, but valid data were only about 37 respondents.

As for the method of assessment by respondents, researchers provided 31 data in the form of source language texts and target language texts compiled from 11 translation techniques. Then respondents were asked to give a score of 3.2, or 1 , in each column aspects of accuracy, acceptance, and legibility. A score of 3 indicates very accurately, acceptable, high legibility. A score of 2 indicates inaccurate, less acceptable, moderate legibility. And a score of 1 indicates inaccurate, unacceptable, low legibility. Following is the explanation of the results of the translation quality assessment.

a) Literal Translation

The assessment of the accuracy, acceptance, and legibility aspects of the four data samples translated using the literal translation technique carried out by 37 respondents is presented in this and diagram:
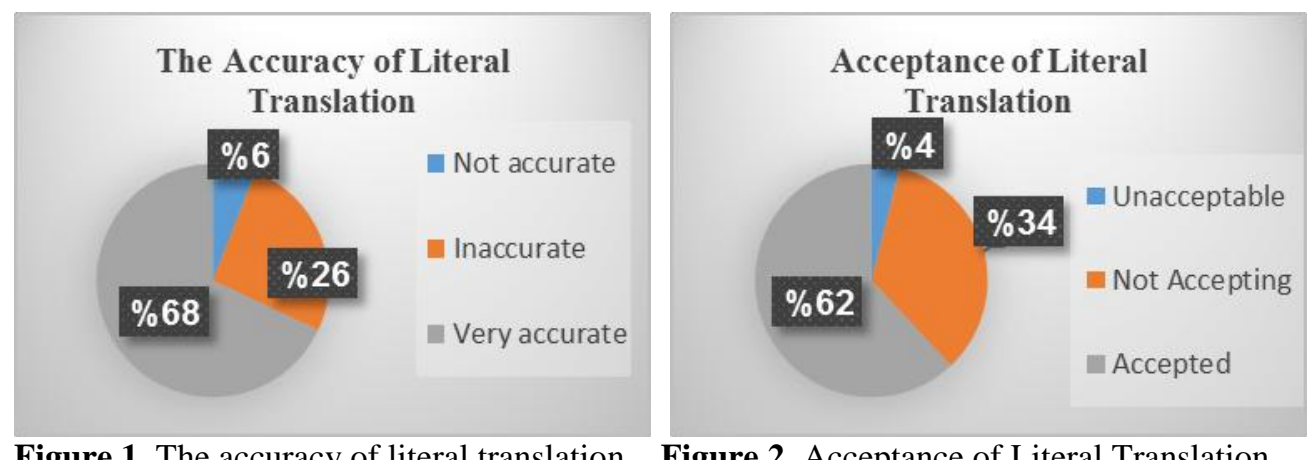

Figure 1. The accuracy of literal translation

Figure 2. Acceptance of Literal Translation

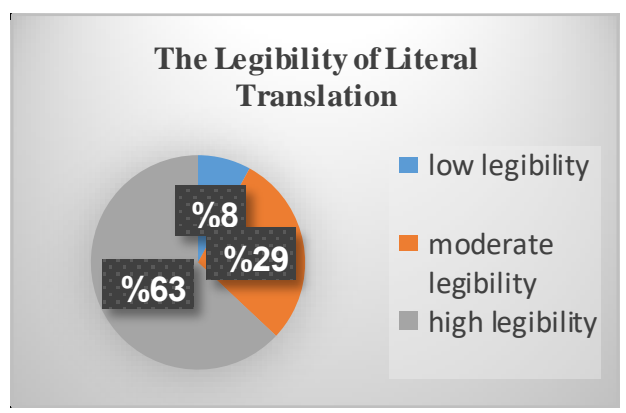

Figure 3. The Legibility of Literal Translation 
From the table and diagram above, it can be seen that as many as 25 respondents (68\%) rated translation using literal translation techniques to be very accurate. Besides, as many as 10 respondents $(26 \%)$ rated the translation using literal translation techniques to be inaccurate, and two respondents $(6 \%)$ rated the translations using literal translation techniques to be not accurate.

Assessment of translation quality using literary translation techniques in terms of acceptance, 23 respondents (62\%) rated accepted, 13 respondents (34\%) ranked not accepting, and only one respondent (4\%) assessed unacceptable. In addition to the accuracy and acceptability aspects, assessment of the quality of translations using literary translation techniques is also viewed from the aspect of legibility. Assessment of the legibility aspect of the data using this literal translation technique, as many as 23 respondents (63\%) rated high legibility, 11 respondents $(29 \%)$ rated it with moderate legibility, and three respondents (8\%) rated with low legibility.

b) Amplification

The assessment of the accuracy, acceptance, and legibility aspects of the four data samples translated using the amplification technique carried out by 37 respondents is presented in this and diagram,
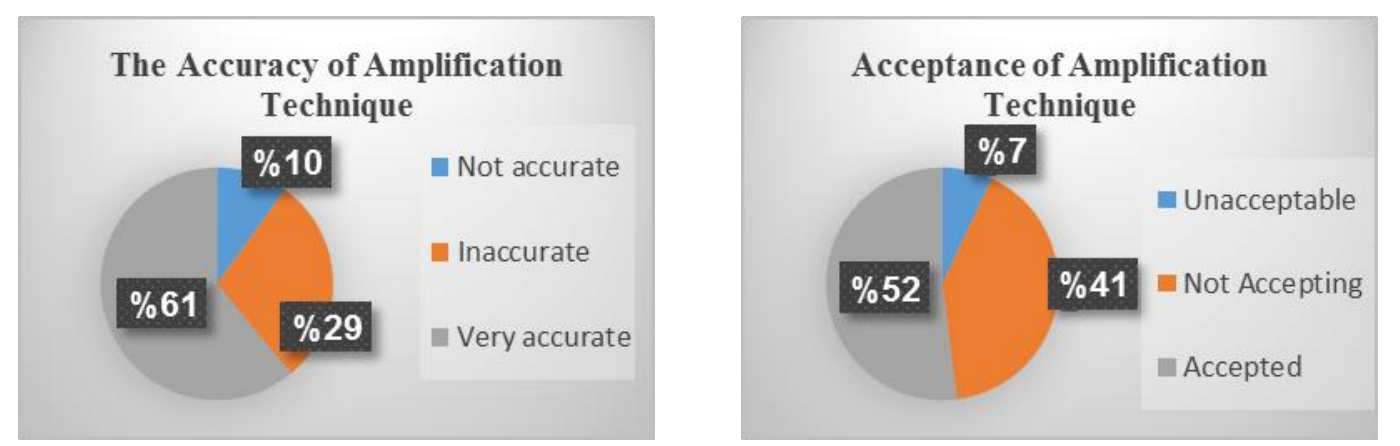

Figure 4. The accuracy of amplification technique Figure 5. Acceptance of amplification technique

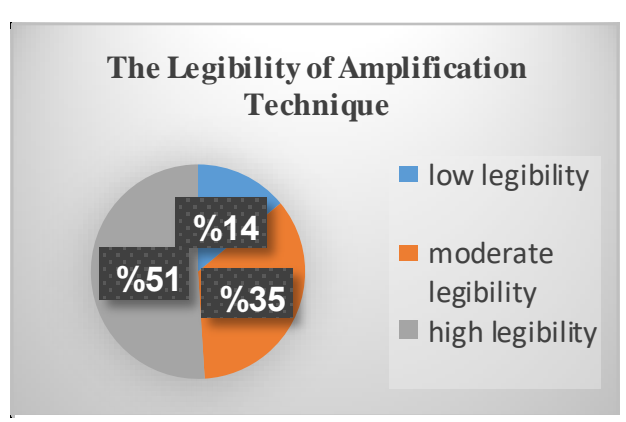

Figure 6.The Legibility of amplification technique

From the table and diagram above, it can be seen that as many as 23 respondents (61\%) rated translation using amplification techniques to be very accurate. Besides, as 
many as 11 respondents (29\%) rated the translation using amplification techniques to be inaccurate, and 3 respondents $(10 \%)$ rated the translations using amplification techniques to be not accurate.

Assessment of translation quality using amplification techniques in terms of acceptance, 19 respondents (52\%) rated accepted, 15 respondents (41\%) ranked not accepting, and 3 respondent (7\%) assessed unacceptable. In addition to the accuracy and acceptability aspects, assessment of the quality of translations using amplification techniques is also viewed from the aspect of legibility. Assessment of the legibility aspect of the data using this amplification technique, as many as 19 respondents (51\%) rated high legibility, 13 respondents $(35 \%)$ rated it with moderate legibility, and 5 respondents (14\%) rated with low legibility.

c) Borrowing

The assessment of the accuracy, acceptance, and legibility aspects of the four data samples translated using the borrowing technique carried out by 37 respondents is presented in this table and diagram:

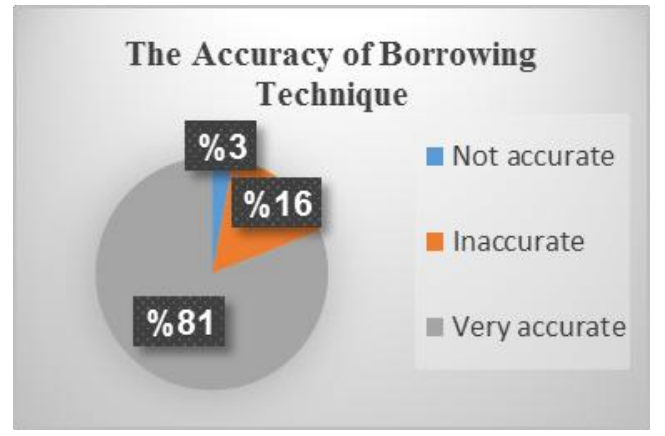

Figure 7. The accuracy of borrowing technique

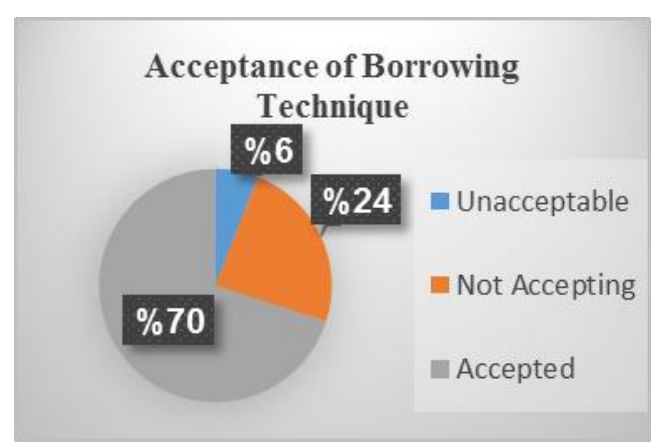

Figure 8. Acceptance of borrowing technique

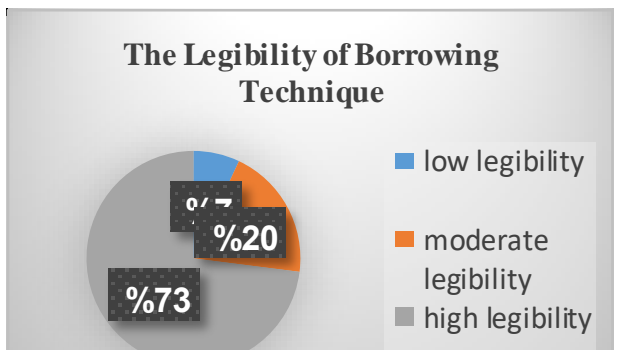

Figure 9. The Legibility of borrowing technique

From the table and diagram above, it can be seen that as many as 30 respondents $(81 \%)$ rated translation using borrowing techniques to be very accurate. Besides, as many as 6 respondents $(16 \%)$ rated the translation using amplification techniques to be 
inaccurate, and 1 respondent ( $3 \%$ ) rated the translations using borrowing techniques to be not accurate.

Assessment of translation quality using borrowing techniques in terms of acceptance, 26 respondents $(70 \%)$ rated accepted, 9 respondents $(24 \%)$ ranked not accepting, and 2 respondents (6\%) assessed unacceptable. In addition to the accuracy and acceptability aspects, assessment of the quality of translations using borrowing techniques is also viewed from the aspect of legibility. Assessment of the legibility aspect of the data using this amplification technique, as many as 27 respondents $(73 \%)$ rated high legibility, 7 respondents $(20 \%)$ rated it with moderate legibility, and 3 respondents $(7 \%)$ rated with low legibility.

d) Adaptation

The assessment of the accuracy, acceptance, and legibility aspects of the four data samples translated using the borrowing technique carried out by 37 respondents is presented in this diagram:
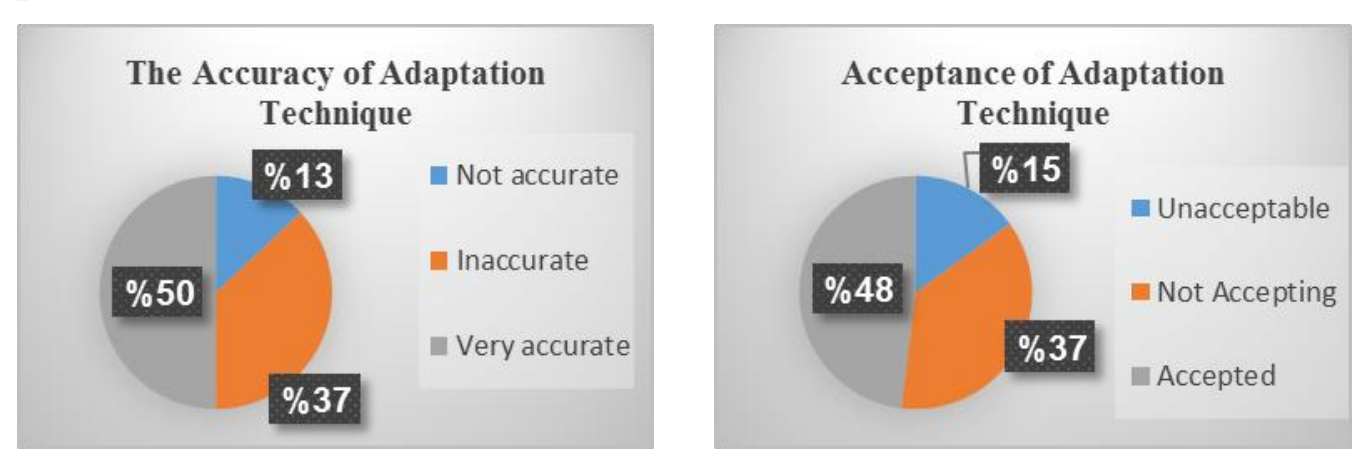

Figure 10. The accuracy of adaptation technique

Figure 11. Acceptance of adaptation technique



Figure 12. The Legibility of adaptation technique

From the table and diagram above, it can be seen that as many as 18 respondents (50\%) rated translation using adaptation techniques to be very accurate. Besides, as many as 14 respondents (37\%) rated the translation using adaptation techniques to be inaccurate, and 5 respondents $(13 \%)$ rated the translations using adaptation techniques to be not accurate. Assessment of translation quality using adaptation techniques in terms of 
acceptance, 18 respondents (48\%) rated accepted, 14 respondents (37\%) ranked not agreeing, and 5 respondents (15\%) assessed unacceptable.

In addition to the accuracy and acceptability aspects, assessment of the quality of translations using adaptation techniques, it is also viewed from the aspect of legibility. Assessment of the legibility aspect of the data using this amplification technique, as many as 20 respondents (55\%) rated high readability, 12 respondents $(33 \%)$ rated it with moderate legibility, and 5 respondents (12\%) rated with low readability.

e) Compensation

The assessment of the accuracy, acceptance, and legibility aspects of the four data samples translated using the compensation technique carried out by 37 respondents is presented in this diagram:

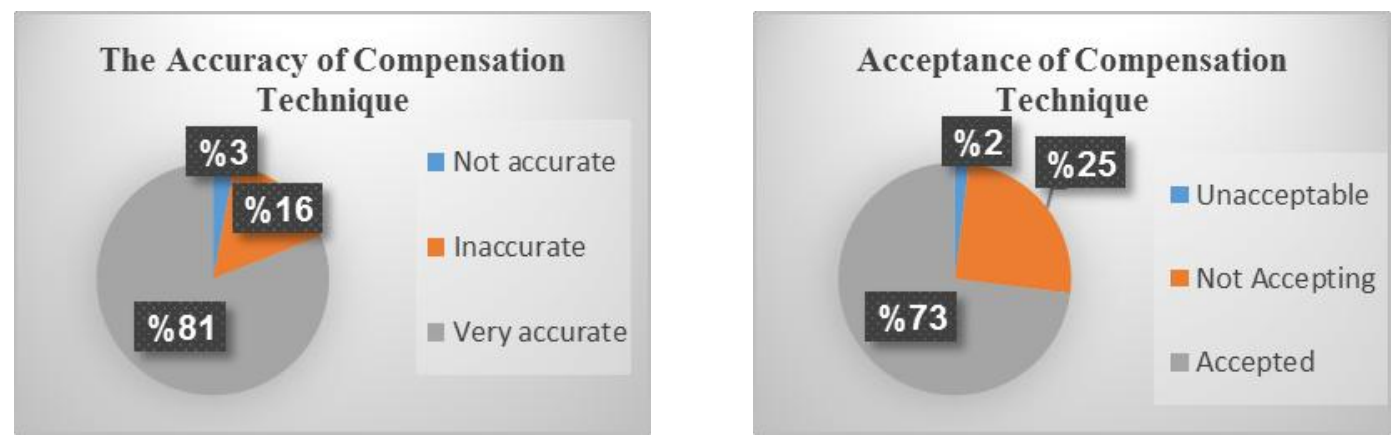

Figure 13. The accuracy of compensation technique Figure 14. Acceptance of compensation technique

The Legibility of Compensation Technique

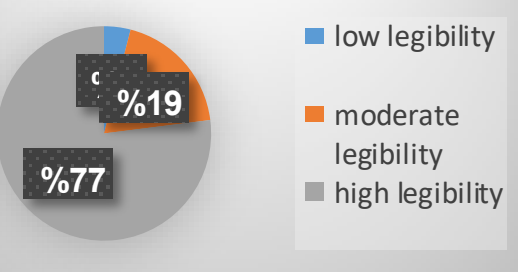

Figure 15. The Legibility of compensation technique

From the table and diagram above, it can be seen that as many as 30 respondents $(81 \%)$ rated translation using compensation techniques to be very accurate. Besides, as many as 6 respondents $(16 \%)$ rated the translation using compensation techniques to be inaccurate, and 1 respondent (3\%) rated the translations using compensation techniques to be not accurate.

Assessment of translation quality using compensation techniques in terms of acceptance, 27 respondents $(73 \%)$ rated accepted, 9 respondents $(25 \%)$ ranked not 
accepting, and 1 respondent (2\%) assessed unacceptable. In addition to the accuracy and acceptability aspects, assessment of the quality of translations using compensation techniques, it is also viewed from the aspect of legibility. Assessment of the legibility aspect of the data using this amplification technique, as many as 28 respondents (77\%) rated high legibility, 7 respondents (19\%) rated it with moderate legibility, and 2 respondents $(4 \%)$ rated with low legibility.

\section{Conclusion}

From the analysis, it can be concluded as follows: 1) literal translation technique is the most widely used in translating the 64 data of idhafi phrases. These translation techniques consist of literal translation, amplification, borrowing, adaptation, compensation, description, discursive creation, reduction, generalization, modulation, and transposition. However, from its quality, compensation techniques and description techniques are considered to have excellent quality in conveying intentions, messages, and objectives to the reader in the target language. This is because the information elements or the stylistic influence of the source language text on the target language text can help the reader to understand the intent, message, and purpose to be conveyed. In addition to compensation, the quality of the described technique is also quite good, because, with the help of the description provided by the translator, it is beneficial to the reader in understanding the intentions, messages, and objectives conveyed. We suggest that future studies will focus more on the quality of translation rather than its technique. It is because the translator has its particular method in some cases that may differ from the mentioned techniques.

\section{Acknowledgment}

The authors would like to acknowledge the Department of Arabic Language and Literature of Universitas Ahmad Dahlan and Department of Arabic Language \& Linguistics, Islamic International University College Selangor, Malaysia for supporting this working paper in the form of joint co-authorship as the implementation of the MoU.

\section{References}

Akbari, Monireh. "Strategies for Translating Idioms," Journal of Academic and Applied Studies (Special Issue on Applied Linguistics), 3, no. 8 (2013): 32-14. 
Akmaliyah, A. "Model Dan Teknik Penerjemahan Kalimat Bahasa Arab Ke Dalam Bahasa Indonesia," Al-Tsaqafa: Jurnal Ilmiah Peradaban Islam, 13 (01) (2016): 125-34.

Al-Munawwir, Ahmad Warson, 'Kamus Al-Munawwir Arab-Indonesia Terlengkap', Pustaka Progressif (Yogyakarta, 1997)

Alsrhid, Arif Mohammed Mufleh, 'Difficulties Face by Foreign Students in Learning Arabic Language Programs for Non-Native Speakers (Evaluation Study)', Learning, 4.2 (2013), 160-70

Baharudin, Harun. "Strategi dan Teknik Terjemahan Novel Arab dalam Kalangan Pelajar Universiti (Arabic Novel Translation Strategies and Techniques used among University Students)." GEMA Online® Journal of Language Studies 17.4 (2017): 225-243, http://dx.doi.org/10.17576/gema-2017-1704-15.

Buska, Wahyudi, Yogia Prihartini, and Nur Hasnah, 'Analysis of Students' Arabic Proficiency for Vocabulary Mastery in State Islamic Junior High School in Muaro Jambi', INNOVATIO: Journal for Religious Innovation Studies, 18.1 (2018), 51-62 <https://doi.org/https://doi.org/10.30631/innovatio.v18i1.40>.

Carreres, Ángeles, and María Noriega-Sánchez. "Translation in Language Teaching: Insights from Professional Translator Training," The Language Learning Journal, 39, no. 3 (2011): 281-97.

Esposito, Noreen. "From meaning to meaning: The influence of translation techniques on non-English focus group research." Qualitative health research 11, no. 4 (2001): 568-579.

Gouadec, Daniel. Translation as a Profession. Vol. 73. Amsterdam: John Benjamins Publishing, 2007.

Hendrastuti, Retno. "Kajian Terjemahan Metafora yang Menunjukkan Sikap dalam Buku Motivasi The Secret." TransLing Journal: Translation and Linguistics 1, No. 1 (2013).

Holes, Clive, Modern Arabic: Structures, Functions, and Varieties (Washington: Georgetown University Press, 2004)

Huehnergard, John, 'Arabic in Its Semitic Context', in Arabic in Context (Leiden: Brill, 2017), pp. 3-34 <https://doi.org/https://doi.org/10.1163/9789004343047_002>.

Kobyakova, Iryna and Svitlana ShvacErtnohko "Teaching Translation: Objectives and Methods." Advanced Education (2016): 9-13, https://doi.org/10.20535/24108286.61029 .

Lewis, Bernard, Semites and Anti-Semites: An Inquiry into Conflict and Prejudice (New York and London: WW Norton \& Company, 1999) 
Majid, Latifah Abdul, and Nurullah Kurt. "Bahr Al-Madhi: Significant Hadith Text Sciences for Malay Muslims as a Tool for Political Teaching during Twentieh Century," Mediterranean Journal of Social Sciences, 5, no. 20 (2014): 2249.

Mayer, Isabella. "Qualitative Research with a Focus on Qualitative Data Analysis," International Journal of Sales, Retailing \& Marketing, 4, no. 9 (2015): 53-67.

Molina, L, Albir, A.H. "Translation Techniques Revisited: A Dynamic and Functionalist Approach." Les Presses de l'Université de Montréal, Journal des traducteurs, 47, no. 4 (2002): 498-512., id.erudit.org/iderudit/008033ar https://doi.org/10.7202/008033ar.

Murtafi, Anshoffy, Nababan Nababan, and Djatmika Djatmika. "Analisis Terjemahan Gaya Bahasa Repetisi Dalam Novel A Thousand Splendid Suns, Teknik Dan Kualitasnya (Kajian Penerjemahan Dengan Pendekatan Stilistika)." PRASASTI: Journal of Linguistics 2.1 (2017): 1-20.

Nababan, Mangatur, 'Aspek Genetik, Objektif, Dan Afektif Dalam Penelitian Penerjemahan', Linguistika, 14.26 (2007), 15-23

, 'Kecenderungan Baru Dalam Penerjemahan', Englonesian: Jurnal Ilmiah Linguistik Dan Sastra, 2.1 (2006), 68-73

Neubert, Albrecht, 'Competence in Language, in Languages, and in Translation', Benjamins Translation Library, 38 (2000), 3-18 <https://doi.org/https://doi.org/10.1075/btl.38.03neu>

Olk, Harald Martin, 'Cultural References in Translation: A Framework for Quantitative Translation Analysis', Perspectives, $21.3 \quad$ (2013), $344-57$ <https://doi.org/10.1080/0907676X.2011.646279>

Rahmawati, Anindia Ayu, Nababan Nababan, and Riyadi Santosa, 'Kajian Teknik Penerjemahan Dan Kualitas Terjemahan Ungkapan Yang Mengandung Seksisme Dalam Novel The Mistress's Revenge Dan Novel The 19th Wife', Prasasti: Journal of Linguistics, $\quad 1.2 \quad$ (2016), $249-70$ <https://doi.org/https://doi.org/10.20961/prasasti.v1i2.1032>

Rohana, Yogi, Riyadi Santosa, and Djatmika Djatmika, 'Gaya Bahasa, Teknik Penerjemahan, Dan Kualitas Terjemahan Dalam Dongeng Disney Dwibahasa Berjudul Cinderella: My Bedtime Story Dan Tinkerbell And The Great Fairy Rescue.', PRASASTI: Journal of Linguistics, 2.1, 150-66 <https://doi.org/https://doi.org/10.20961/prasasti.v2i1.1736>

Torop, Peeter, 'Translation as Translating as Culture', $\Sigma \eta \mu \varepsilon l \omega \tau \kappa \eta$-Sign Systems Studies, 30.2 (2002), 593-605

Yoyo, Yoyo, and Abdul Mukhlis, 'Historiography of the Arabic Grammar in Europe: The Legacy of Wright's Arabic Grammar', in First International Conference on Progressive Civil Society (ICONPROCS 2019) (Atlantis Press, 2019), pp. 212-15 <https://doi.org/https://doi.org/10.2991/iconprocs-19.2019.45> 
Yoyo, Yoyo, Abdul Mukhlis, Thonthowi Thonthowi, and Ferawati Ferawati, 'High Variety Vs Low Variety Culture in the Arabic Language: The Tensions between Fushā and 'Âmiyya in the Contemporary Arab World', Arabi: Journal of Arabic Studies,5.1(2020),25-32 <https://doi.org/http://dx.doi.org/10.24865/ajas.v5i1.195>. 